Yüzüncü Yil Üniversitesi
Tarim Bilimleri Dergisi

Araştırma Makalesi (Research Article)

Determination of the Efficiency of Resource Utilization of Agricultural Enterprises in Urban Sprawl; in Case of Konya Province

\author{
Zuhal KARAKAYACI ${ }^{* 1}$ \\ ${ }^{1}$ Selcuk University Agricultural Faculty Department of Agricultural Economics, 42070, Konya, Turkey \\ *Corresponding Author e-posta: zkarakayaci@gmail.com
}

\section{Article Info}

Received: 09.05.2019

Accepted: 21.08.2019

Online Published 30.09.2019

DOI: 10.29133/yyutbd.562194

Keywords

Cost Minimization,

Efficiency,

Profitability,

Scale Inefficiency.

\begin{abstract}
The economic profitability explains operational capital usage efficiency of the agricultural enterprises in the urban sprawl according to the opportunity cost. Agricultural enterprises show different structure according to the characteristics of the environment, and it is observed that the enterprises in the urban sprawl are different from those in rural areas. Because of the loss of rural character under the pressure of urbanization, there are significant differences in the capital structure of agricultural enterprises in urban sprawl in terms of building and land capital. In this study, economic profitability is determined as low as $1.16 \%$. In study area, 91 sample enterprises are identified according to stratified random sampling method. Data Envelopment Analysis is used to determine the technical effectiveness of agricultural lands in the urban sprawl. In examined enterprises, the average technical efficiency score per enterprise is calculated as $0.59(0.589)$ as a result of the analysis. This value explains that $41 \%$ of the variables in the model are inactive. The reason of this ineffectiveness is determined as the interest and depreciation of land and housing capital. Pure technical efficiency ratio which describes the suitability of the combination of the production factors is determined as 0.70 and the scale efficiency which describes the proportional cohesion between production amount and used resources is determined as 0.83 . In order to eliminate this inefficiency due to the high level of housing and land capitals, the entrepreneurs should be directed to ensure that they use the resources effectively.
\end{abstract}

\title{
Kent Saçağındaki Tarım İşletmelerinin Kaynak Kullanım Etkinliğinin Belirlenmesi; Konya ili Örneği
}

\section{Makale Bilgileri}

Geliș: 09.05.2019

Kabul: 21.08.2019

Online Yayınlanma 30.09.2019

DOI: $10.29133 /$ yyutbd.562194

Anahtar kelimeler

Masraf Minimizasyonu, Etkinlik,

Rantabilite,

Ölçek Etkinsizliği.
Öz: Tarım işletmelerinde ekonomik rantabilite, üretim amacıyla yer alan sermayenin firsat maliyetinden daha fazla kar elde edip etmediğini açıklamaktadır. İşletmelerin sürdürülebilirliği açısından kaynakların etkin kullanılması ve rantabilitenin yüksek olması son derece önemlidir. Tarım işletmeleri bulunduğu çevrenin özelliklerine göre farklı yapı göstermekte olup, kent saçağındaki işletmelerin kırsal alandakilere göre farklı olduğu gözlenmektedir. Kentleşmenin baskısı altında kırsal niteliğini kaybettiği için kent saçağındaki tarım işletmelerinin sermaye yapısında bina ve arazi sermayesi açısından önemli farklılıklar bulunmaktadır. Kentsel alan özelliklerinin kısmen görüldüğü kent saçağında tarım arazilerinin arsaya dönüşme beklentisi ve konutların kentsel konut kalitesinde olması bu sermayelerin kırsal alana oranla çok yüksek olmasına neden olmaktadır. Bu durum, işletmelerin rantabilitesini olumsuz yönde etkilemekte olup, çalışmada ekonomik rantabilite \%1.16 oranında çok düşük belirlenmiştir. Çalışma alanında tabakalı tesadüfi örnekleme yöntemine göre 91 örnek belirlenmiştir. Çalışmada, kent saçağındaki tarım 
arazilerinin teknik etkinliğini belirlemek amaciyla Veri Zarflama Analizinden yararlanılmıştır. Analizde bağımlı değişken olarak ekonomik rantabilite, bağımsız değişken olarak toprak, konut, hayvan, alet-makine sermayeleri, işletme masrafları ve aktif sermaye faizi ele alınmıştır. Analiz sonucunda, incelenen işletmelerde işletme başına ortalama teknik etkinlik skoru yaklaşık 0.59 (0.589) olarak hesaplanmıştır. Bu değer modelde yer alan değişkenlerin \% 41 etkinsiz olduğunu açıklamaktadır. Saf teknik etkinlik 0.70 , ölçek etkinliği 0.83 olarak belirlenmiştir. Konut ve arazi sermayelerinin yüksek olmasından dolayı meydana gelen ölçek etkinsizliğinin giderilmesi için işletmecilerin kaynakları etkin bir şekilde kullanmasını sağlamak üzere yönlendirilmesi gerekmektedir.

\section{Introduction}

It is observed that agricultural activities are still continuing in the urban sprawl, which are the areas between the city and the rural area and includes uncertainty. The loss of its unique structure by urban sprawl affects the activities of agricultural enterprises. It is observed that agricultural activities change over time and tend to decrease in these areas which are in the process of urban transformation. Therefore, it can be seen that the socio-economic structure of agricultural enterprises in this area is different from the agricultural enterprises in rural areas.

Under the conditions of pure competition, the profit maximization is the main purpose. There are two basic principles to achieve this purpose. The first one is to get the highest revenue with a certain cost, and the second is to reach a certain income with the lowest cost. In both principles, rational use of resources is important. The most important issue of the production economy in which competition in production has come to the forefront in the last 30 years is the efficient use of scarce resources. The most important efforts of the enterprises that produce in both agricultural production and non-agricultural sectors are to reduce the cost. The most common way to reduce costs is to increase production efficiency (Bayramoğlu et al., 2010).

The success of the agricultural enterprises is determined by the analysis of the capital utilization efficiency and obtained income as a result of participation of capital elements to production. In addition, it is accepted that the only use of the capital involved in production is agricultural activity. However, the fact that the non-agricultural demand of the building and land capital in the agricultural enterprises located in the urban sprawl gives the feature of being an investment tool to these capital elements. These capital elements also have a profitability even if they are not used in agricultural production and they do not cause loss of income of their owners. It is possible to obtain income with the increase of value of the building and land capital as an investment tool. Because of the expectation of transformation of agricultural lands to plot and the utilization of the houses' infrastructure and social opportunities cause the value increase.

Economic profitability shows the success of the capital used in the production activity of the enterprise. In other words, the profitability explains whether the capital which is for production in the enterprise produces more profit than the opportunity cost. It also explains whether the business capital is proportional to the economic activity performed. As a matter of fact, while fixed capital investments determine the limits of the production capacity of the enterprise, revenue assets investments determine the production efficiency of the enterprise. Thus, both fixed and revenue assets, which determine the active capital, have a direct effect on the operating net profit. In return for the increase in active capital or the total capital, it is desired that the net profit of the enterprise increases, and the profitability is higher than the opportunity cost. This situation is important in terms of economic sustainability of enterprises.

The sustainability of agricultural enterprises is extremely important in order to maximize the welfare of the agricultural sector and the sustainability of the enterprise is directly proportional to the economic structure (Arısoy et al., 2017). It is easier that ensuring environmental, social and technical sustainability of enterprises with high economic development (Bayramoğlu et al., 2018). However, it is observed that there is no sustainability in agricultural enterprises in the urban sprawl. Adelaja et al. (2011) in their study in New Jersey, it is determined that in the urban sprawl, agricultural enterprises do not have a forward planning process. This complex situation, which has economic, social and 
environmental impacts on urban sprawl, causes countries to change their land use policies (Bittner and Sofer, 2013). The rapid growth of urbanization in urban sprawl and the transformation of agricultural land to plot and the increase in land value destroy the sustainability of agricultural activities. In fact, in his study of Oueslati et al. (2013), they determined that urban sprawl in Europe hampered agricultural productivity. On the other hand, the high value of the agricultural lands close to the city is the most important feature of the urban sprawl (Bayramoglu and Gundogmus, 2008; Karakayac1, 2018). Within the scope of this study, the adequacy of the economic profitability which explains the capital structure of the agricultural enterprises of this type and the profitability of operating costs has been investigated.

\section{Material and Methods}

The material of the study consists of the data obtained from the surveys conducted with agricultural enterprises in the city of Konya in urban sprawl. According to stratified random sampling method, the number of samples is calculated using the following formula (Yamane, 1967).
$\mathrm{n}=\frac{\Sigma(\mathrm{Nh} . \mathrm{Sh})^{2}}{\mathrm{~N}^{2} \cdot \mathrm{D}^{2}+\Sigma\left(\mathrm{Nh} \cdot S h^{2}\right)}$
$\mathrm{D}^{2}=\mathrm{d}^{2} / \mathrm{z}^{2}$
In formula;
n: Number of samples,
$\mathrm{N}$ : Number of enterprises in population.
$\mathrm{N}_{\mathrm{h}}$ : Number of enterprises in the layer $\mathrm{h}$.
$S_{h}$ : The variance of layer $h$.
d: The margin of error allowed from the population average,
$\mathrm{z}$ : It refers to the $\mathrm{z}$ value in the standard normal distribution table according to the error rate.

Sample size was determined 99\% confidence interval and 5\% error margin. As a result of the sampling, 91 sample enterprises are identified, 16 of the enterprises with width 0-30 in the first layer, 41 of the enterprises with a width of 31-120 and 34 of the enterprises with a width of 121 and over are surveyed.

Economic profitability is calculated in order to measure the profitability of agricultural enterprises in the urban sprawl, The total capital of the enterprise (active capital) and the net product corresponding to active capital are proportioned (Oğuz and Bayramoğlu, 2018).

Economic
Profitability

$$
=\frac{\text { Net Product }}{\text { Total Enterprise Capital }} \times 100
$$

The net product is defined as the best measure of success in enterprise analysis and comparison. The net product is the remaining portion after subtracting the operating costs from the gross product and it is called the interest of the active capital. Gross product is the monetary value of the final goods and services produced in an enterprise in a calendar year. Operating costs are derived by subtracting the interest on active capital from production costs (Oğuz and Bayramoğlu, 2018).

Net Product $=$ Gross Product - Operating Cost

Operating cost $=$ Production Cost - Interest on active capital

The gross product is obtained by the sum of plant and animal production values, agricultural non-operating income and housing rent. Production cost includes the current costs incurred for the realization of production, the labor costs, the depreciation costs and the interest income of the active capital. In the active capital, which is the capital elements that the operator invests with the purpose of production, land, land reclamation, building, plant, animal, tool-machine, material and money capital are had.

The economic efficiency which is a measurement method to reveal the production efficiency of enterprises is composed of two components; resource utilization efficiency and technical efficiency. Technical efficiency shows the ability to reach maximum production quantity with a certain amount of input (Farrel, 1957; Ceyhan et al., 2004). Total technical efficiency consists of two components; scale efficiency and net technical efficiency.

Total Technical Efficiency $=$ Net Technical Efficiency * Scale Efficiency 
Scale efficiency is also called "success in producing on a suitable scale" (Çaglar, 2003). Net technical efficiency refers to the success of the business manager in managing production factors. Data Envelopment Analysis (DEA), which is a non-parametric method, is used to measure effectiveness (Coelli et al., 2002). The estimation of activity measurements is made in DEAP 2.1 package program developed by Coelli (1996). The economic profitability of the agricultural enterprises in the rural area of Konya was determined as $8 \%$ on average (Bayramoğlu, 2015; Bayramoğlu and Bozdemir, 2018; Ağızan, 2018), and this difference arises from the fact that the capital structure in the urban sprawl is different. The high level of land and building capital in the agricultural enterprises in the urban sprawl due to the non-agricultural demand leads to low economic profitability in these enterprises.

In the study, although the data of 91 agricultural enterprises were taken into consideration, as the homogeneity of the data is important in the Data Envelopment Analysis, the data with the economic profitability are extracted and 82 enterprises are analyzed. In the analysis, economic profitability as a dependent variable, land, housing, animal, tool-machine capital, operating costs and active capital interest are handled as independent variables. In the determination of the independent variables, the total enterprise capital and the sub-components of the net product are taken into account. The efficiency levels and efficiency coefficients of the enterprises whose activity levels are analyzed are determined while the numerical values in Table 1 are used. According to the range of 0.000/0.250 enterprises are fully inactive, $0.251 / 0.500$ between the enterprises inactive, $0.501 / 0.750$ between the enterprises less efficient, 0.751/0.999 between enterprises effective and the value of 1000 businesses are considered to be fully effective.

Table 1. Efficiency Levels and Efficiency Coefficients

\begin{tabular}{lc}
\hline Efficiency Levels & Efficiency Coefficients \\
\hline Fully inactive & $0.000 / 0.250$ \\
Inactive & $0.251 / 0.500$ \\
Less effective & $0.501 / 0.750$ \\
Effective & $0.751 / 0.999$ \\
Fully effective & 1.000 \\
\hline
\end{tabular}

Source: (Bayramoğlu and Bozdemir, 2018).

\section{Results and Discussion}

\subsection{Economic Profitability of Agricultural Enterprises in Urban Sprawl}

The value of real estate's such as land and building capital which are included in fixed capital investment in urban sprawl agricultural enterprises is higher. These assets are high value because of being in the urban sprawl. Because of the potential utilization of agricultural lands for non-agricultural purposes in urban sprawl is high, increases the value.

Because the land values in urban sprawl higher, it causes negative profitability and low profitability in enterprise. Because of the high agricultural value of agricultural land and buildings used for agricultural purposes by agricultural enterprises in urban sprawl has a negative impact on the results of the analyzes and thus the success of the enterprise. The economic profitability is determined as $1.16 \%$, and the adequacy of the profitability is compared with the opportunity cost. Economic profitability ratios were very low due to insufficient return ratio of capital for agricultural enterprises (Topçu, 2018). In this study, the interest rate given by the agricultural bank to deposits is used as an opportunity cost. This rate is determined as 10\% (Ziraat Bank, 2018). 
Table 2. Economic Profitability

\begin{tabular}{lcccc}
\hline & & \multicolumn{3}{c}{ Enterprise Groups } \\
& $0-30$ & $31-120$ & $121-+$ & Average of enterprises \\
\hline Gross Product (GP) (\$) & 20584.46 & 52323.64 & 125193.63 & 73969.27 \\
Operating Costs (\$) & 22420.08 & 44370.57 & 73325.89 & 51329.62 \\
Net Product (\$) & -1835.63 & 7953.06 & 51867.74 & 22639.66 \\
Active Capital (\$) & 215273.42 & 1009532.17 & 3895083.65 & 1948000.41 \\
Economic profitability (\%) & -0.85 & 0.79 & 1.33 & 1.16 \\
\hline
\end{tabular}

*When taking the monetary data of the enterprise. the dollar rate at the time of the transaction was taken into consideration in July 2018 (1 USD \$ = 4.83 Turkish Liras).

Considering this ratio, it is seen that the economic profitability of the examined enterprises is very low. This situation does not change according to the enterprise scales and sufficient profitability has not been achieved in all enterprise groups. Profitability ratios are very important for the sustainability of enterprises. It has been determined that the profitability of the enterprises in the urban sprawl is low and does not have a sustainable profit rate. In fact, it is determined that this is a general feature of the agricultural enterprises in urban sprawl. Sustainable agricultural activity is not expected due to the high potential of utilization for the non-agricultural purposes the agricultural lands of agricultural enterprises in urban sprawl. This situation has also become clear with the profitability of capital.

\subsection{Efficiency Analysis of Agricultural Enterprises in Urban Sprawl}

The resource utilization efficiency of agricultural enterprises operating in the urban sprawl has been analyzed and given in Tables 3. 4 and 5. In the enterprises examined economic profitability is accepted as dependent variable. Economic profitability is one of the most important enterprise success criteria. In calculation the enterprise's net product and the proportion of total capital is used. However, it is sensitive to the productivity in production activities along with the change in all capital elements of enterprises. Therefore, the effectiveness of economic profitability is tried to be explained. In order to explain the economic profitability operating costs and active capital interest are used together with land, housing, animal, tool- machinery capital which are the most important elements of active capital. The factors taken into account as independent variables are the most important determinants of the success of economic profitability. As a matter of fact, operating costs are the most important indicator for the efficiency of production activities. Cost minimization is provided by operating costs.

Table3. Capital Use of Enterprises by Classification of Technical Activity Scores

\begin{tabular}{|c|c|c|c|c|c|c|}
\hline Technical Activity & $\begin{array}{l}\text { Fully } \\
\text { Effective } \\
1.00\end{array}$ & Effective & $\begin{array}{l}\text { Less } \\
\text { Effective } \\
0.63\end{array}$ & Inactive & Fully Inactive & $\begin{array}{l}\text { General Average } \\
0.59\end{array}$ \\
\hline Land Capital (\$) & 635142 & 1094139 & 1267081 & 909046 & 1811594 & 1087411 \\
\hline Building Capital (\$) & 23106 & 121430 & 239906 & 135720 & 113267 & 132249 \\
\hline Animal Capital (\$) & 70945 & 266497 & 102820 & 296902 & 80776 & 194931 \\
\hline $\begin{array}{l}\text { Tool machinery capital } \\
\text { (\$) }\end{array}$ & 22988 & 24496 & 18388 & 50604 & 772.16 & 37865 \\
\hline Operating Costs (\$) & 17350 & 25382 & 57935 & 48778 & 83174 & 44628 \\
\hline $\begin{array}{l}\text { Active Capital Interest } \\
(\$)\end{array}$ & 6610 & 27645 & 12833 & 26774 & 12465 & 19730 \\
\hline Net Profit (\$) & 10457 & -52729 & -29456 & -66072 & -25036 & -40079 \\
\hline Gross Product (\$) & 68255 & 186489 & 85281 & 152187 & 70603 & 125664 \\
\hline Net Product (\$) & 17067 & -25084 & -16623 & -39298 & -12571 & -203.49 \\
\hline
\end{tabular}

The average technical efficiency score per enterprise is calculated about $0.59(0.589)$. This value explains that $41 \%$ of the variables in the model are inactive. In other words, it is explained that the net product obtained in return for the use of the total capital of the enterprise is not at the level of 
the resources used. or that the excess resources are used. Explains that the current net product can be achieved with less capital or operating costs. Table 3 shows the capital structure and operating costs of the decares according to the technical activity classes of the enterprises. Accordingly, land, housing, animal and tool machinery capitals of the enterprises less in per decares in active enterprises than inactive enterprises. Land capital is determined as 635142 \$ / da per decare in fully active enterprises and 1811594 \$ / da in fully inactive enterprises. This situation is the same for other capital elements. Operating costs are lower in fully efficient enterprises than in inefficient enterprises. A matter of fact, operating costs per decare in full-scale enterprises were set at 17350 \$ / da and at 83174 \$ / da in fully inefficient enterprises.

Table 4. Capital Use of Enterprises by Classification of Net Technical Efficiency Scores

\begin{tabular}{lllllll}
\hline Net technical activity & Fully Effective & Effective & $\begin{array}{l}\text { Less } \\
\text { Effective }\end{array}$ & Inactive & Fully Inactive & General Average \\
& 1.00 & 0.79 & 0.58 & 0.37 & 0.17 & 0.70 \\
\hline Land Capital & 1072810 & 897170 & 784334 & 1099495 & 2553485 & 1087411 \\
Building Capital & 147978 & 6843 & 81585 & 157506 & 139053 & 132249 \\
Animal Capital & 193626 & 13870 & 38658 & 307411 & 119388 & 194937 \\
Tool Machinery & 23535 & 17412 & 20216 & 63052 & 96111 & 37867 \\
Capital & & & & & & 109913 \\
Operating Costs & 157522 & 20966 & 41835 & 202725 & 109913 \\
Active Capital Interest & 20527 & 2195 & 4992 & 28646 & 16816 & 19730 \\
Net Profit & -38110 & 4857 & 5.06 & -69752 & -32343 & -40079 \\
Gross Product & 139939 & 28017 & 47333 & 161620 & 94387 & 125664 \\
Net Product & -17583 & 7052 & 5498 & -41106 & -15526 & -20349 \\
\hline
\end{tabular}

According to the results, technical inefficiency is mostly due to net technical inefficiency. Business managers operating in the urban sprawl should be informed about production factors and production activities.

Data envelopment analysis divides enterprises' inefficiencies into two groups as net technical inefficiency and scale ineffectiveness. In this study, the net technical efficiency is determined to be approximately $0.70(0.703)$. Net technical efficiency is the activity that which is the result of direction and management of production factors by the business manager. According to the result, net technical inefficiency is determined as 30\% (Table 4). In the study conducted by Ceyhan et al. (2004), technical efficiency was determined as 0.82 in trout breeding enterprises. Also, Canan et al. (2018) found to be 0.93 in their study carried out in the kiwi growing enterprises. The scale efficiency explains the proportion of the resources used in the enterprise and the scale of the enterprise. Scale efficiency is determined as 0.83 (0.827). According to this value, the scale inefficiency is $27 \%$ (Table 5).

In Table 4 classification made according to net technical efficiency and Table 5 are classified according to scale efficiency and the capital elements and operating costs are averaged according to enterprise classes. In the classification of technical efficiency both in capital and operating costs (Table 3) with the increase of inefficiency, capital and operating costs are increased according to decares.

Table 5. Capital Use of Enterprises by Classification of Scale Technical Efficiency Scores

\begin{tabular}{|c|c|c|c|c|}
\hline Scale Activity & $\begin{array}{l}\text { Fully Effective } \\
1.00\end{array}$ & $\begin{array}{l}\text { Effective } \\
0.86\end{array}$ & $\begin{array}{l}\text { Less Effective } \\
0.66\end{array}$ & $\begin{array}{l}\text { General Average } \\
0.83\end{array}$ \\
\hline Land Capital & 6351.42 & 10475.54 & 14048.23 & 10874.11 \\
\hline Building Capital & 231.08 & 1523.72 & 1480.71 & 1322.49 \\
\hline Animal Capital & 709.57 & 2808.91 & 839.76 & 1949.37 \\
\hline Tool machinery Capital & 229.92 & 467.98 & 273.78 & 378.67 \\
\hline Operating Costs & 511.88 & 2012.55 & 826.00 & 1460.13 \\
\hline Active Capital İnterest & 66.10 & 272.27 & 112.56 & 197.30 \\
\hline Net Profit & 104.57 & -543.76 & -372.29 & -400.79 \\
\hline Gross Product & 682.55 & 1741.06 & 566.27 & 1256.64 \\
\hline Net Product & 170.67 & -271.50 & -259.73 & -203.49 \\
\hline
\end{tabular}


The scale ineffectiveness is that the capital elements and operating costs used in the enterprise are more than the scale of the enterprises (Bayramoğlu and Bozdemir, 2018; Candemir and Kizılaslan, 2019). Especially the agricultural enterprises in urban sprawl, high land and housing capital can be explained as the reason for this inefficiency. As a matter of fact, with the high rate of ground rent agricultural land in urban sprawl and the non-agricultural purpose demand, the values are very high. For this reason, interest and depreciation costs of the housing capital together with the interest cost of the land adversely affect the economic profitability. As a matter of fact, interest expenses are included in the active capital included in the model and depreciation is included in operating expenses.

Efficiency scores are classified in the study and according to this classification, enterprise success criteria such as net profit, pure product and gross product were compared with the variables included in the model of the enterprise groups. When the examined enterprises are classified according to technical activities. $14.63 \%$ of the enterprises are fully effective, $23.17 \%$ are effective, $18.29 \%$ are less effective, $31.71 \%$ are inactive and $12.20 \%$ are fully inactive group. In a study conducted by Bayramoğlu et al. (2010) in Çanakkale, $81.54 \%$ of the enterprises were found to be ineffective when evaluated in terms of technical efficiency.

\section{Conclusion}

Effective use of resources is important in terms of cost minimization. As a matter of fact, when the resources are used effectively. the minimum cost level can be reached. According to the results obtained in this study, the inefficiency value for the cost minimization or the efficient use of the resources is determined as $41 \%$. The reason of this inefficiency is determined as net technical efficiency and scale efficiency. In order to be able to remedy this, it is important in terms of minimization of costs and resource utilization to inform enterprise managers about management and production activities and also to inform them about aquaculture, marketing and input procurement. Inefficiency caused by scale efficiency is the general feature of agricultural enterprises in urban sprawl. As a matter of fact, the value of land and housing capital. which are considered as property in agricultural enterprises in urban sprawl. are determined to be high due to non-agricultural factors. It is known that these properties are the basic elements of the agricultural production activity. However, it is highly probable that agricultural lands in urban sprawl will be used out of non-agricultural and production activities in the future. In this case, the value of these properties is not expected to decrease. This situation shows that continuous scale inefficiency can be seen in agricultural enterprises in the urban sprawl.

The characteristics of the agricultural enterprises in urban sprawl cause scale in efficiency. In order to eliminate this inefficiency due to the high level of housing and land capitals, studies should be made to direct the entrepreneurs to ensure that they use the resources effectively. With the pressure of urbanization, it is necessary to prevent the destruction of the agricultural potential in urban sprawl. For this purpose, by evaluating the advantage of the proximity of urban sprawl to the city, the high value added production pattern can be expanded and the profitability of the agricultural enterprises in this field can be achieved and the production potential that the agricultural sector and the national economy needs can be obtained.

\section{References}

Adelaja, A. Sullivan, K. \& Hailu Y.G. (2011). Endogenizing the planning horizon in urban fringe agriculture. Land Use Policy. 28, 66-75.

Ağızan, S. (2018). Tarımsal sulama sistemlerinin karşılaştırmalı yatırım analizi; Konya İli Çumra İlçesi örneği (Yüksek Lisans Tezi), Selçuk Üniversitesi Fen Bilimleri Enstitüsü Tarım Ekonomisi Anabilim Dalı, Konya.

Arisoy, H., Bayramoglu, Z., Karakayaci, Z. \& Oguz, C. (2017). The effect of agricultural support on the economic sustainability of agricultural enterprises. Custos e agronegócio on line. 13 (3), 233-253.

Bayramoglu, Z. \& Gundogmus, E. (2008). Farmland values under the influence of urbanization a case study from Turkey. Journal of Urban Planning and Development 134 (2), 71-77. 
Bayramoğlu, Z., Aktürk, D. \& Tatlıdil, F.F. (2010). Kaynakların rasyonel kullanımının üretim maliyetleri üzerine etkisi: Kanola Yetiştiriciliği Örneği. Selcuk University Journal of Selcuk Agriculture and Food Sciences 24 (3), 62-68.

Bayramoğlu, Z., Çelik, Y., Gündüz, O. \& Karakayacı, Z., (2015). Tarımsal İşletme Tipolojilerine Göre Risk Faktörlerinin Algllanması ve Risk Yönetim Stratejilerinin Belirlenmesi, TÜBİTAK 1001 Projesi, Proje No: 113K429.

Bayramoglu, Z., Oguz, C., Karakayaci, Z. \& Arısoy H (2018). Identification of the income level needed for agricultural enterprises to achieve economic sustainability. Economic Research. 31(1), 510-520.

Bayramoglu, Z. \& Bozdemir, M. (2018). Dane Mısır Üretiminde Kaynak Kullanımının Etkinliğinin Belirlenmesi: Konya İli Örneği. Atlas Akademi.

Bittner C, Sofer M (2013). Land use changes in the rural-urban fringe: an Israeli case study. Land Use Policy. 33, 11-19.

Canan, S., Abacı, N.İ., Ceyhan, V. \& Demiryürek, K. (2018). Samsun ili Çarşamba ilçesinde kivi yetiştiren tarım işletmelerinin üretim etkinliği, Mediterranean Agricultural Sciences 31(3), 249-254.

Candemir, S. \& Kizilaslan, N. (2019). Determination of technical efficiency of soybean producing enterprises in Adana, Turkey. Turkish Journal of Agriculture-Food Science and Technology 7(1), 43-48.

Ceyhan, V., Cinemre, H.A., Bozoğlu, M., Demiryürek, K. \& Kiliç, O. (2004). Economic efficiency in trout enterprises in the region of Black Sea. VI. Agricultural Economics Congress. 16-18 September. Tokat. p.255-262. in Turkish

Coelli, T. (1996). A Guide to DEAP Version 2.1: A Data Envelopment Anaylsis (Computer) Program. Centre for Efficiency and Productivity Analysis Working Paper. 96/08. Armidale.

Coelli, T., Rao, D.S.P. \& Battese, G. E. (2002). An Introduction to Efficiency and Productivity Analysis. Kluwer Academic Publishers. Sixth Printing. USA.

Çaglar, A. (2003). Veri Zarflama Analizi ile Belediyelerin Etkinlik Ölçümü. (PhD), Hacettepe Üniversitesi. Fen Bilimleri Enstitüsü. İstatistik Anabilim Dalı, Ankara.

Farrell, M. J. (1957). The Measurement of Productive Efficiency. Journal of Royal Statistical Society. Series A. CXX. Part 3. p. 253-290.

Karakayaci, Z. (2018). Regression analysis for the factor affecting on farm land/urban land value in urban sprawl. Turkish Journal of Agriculture-Food Science and Technology 6 (10), 13571361.

Oguz, C. \& Bayramoglu, Z. (2018). Agricultural Economics. Atlas Akademi. February 2014. Konya.

Oueslati, W., Salanie, J. \& Wu, J. (2018). Urbanization and agricultural productivity: some lessons from European cities. Journal of Economic Geography. 1-25.

Topçu, Y. (2018). Erzurum ili süt sığırcılığı işletmelerinin sermaye yapısına dayalı risk düzeyleri. Yuzuncu Yll University Journal of Agricultural Science 28 (2): 154-6160.

Yamane, T. (1967). Statistics: An Introductory Analysis. 2nd Edition. New York: Harper and Row.

Ziraat Bankası. (2018). https://www.ziraatbank.com.tr/tr/fiyatlar-ve-oranlar, Erişim Tarihi:16.07.2018. 